\title{
流域環境資源調查の方法 一瀬戸川の事例—
}

1.はじめに

近年，地球規模の環境問題の提起によって市民の 環境に関する意識は高まり，我が国でも公共事業に おいて環境保全に配慮を行うことが重要とされてき ている．特に，河川事業においては明治29年にはじ めて制度化された「治水」を目的とした河川法に， 昭和39年「利水」の目的が加えられ，平成 9 年には 「良好な河川環境の整備と保全」を目的とする「環 境」が加えられた。ささらに，整備計画の策定には流 域に暮らす人々の意見を反映させるための仕組みが 作られるようになった。

計画者が住民の意見を充分聞き，住民に理解を得 られる整備計画を策定するためには，住民への適正 な情報公開や地域の環境の詳細な把握がなければな らない。また，住民に地域の環境特性や課題を伝え， 地域の環境保全, 復元, 活性化の方策を考元る手法 として，ワークショップ，観察会，流域環境マップ の作成などが各地で試みられるようになった。

環境マップの作成は旧来より行われていたが，や やもすると現時点の施設の所在を表すだけの観光マッ プ的な作られ方が見られるようだ。しかし，たとえ ば生物調查の結果をもとに生息場所を地図上に精度 を保って特定することは非常に難しいものである. 用いる調査資料によっても位置関係は違ってしまう だけでなく，近年，急激に姿を消しつつある生物や 帰化種 (外来種) の存在も目立っている. 歴史文化 調査では忘れ去られようとしている伝承説話や史跡 が明らかになることもある．河川改修によってなく なった子どもたちの川遊びの場所も浮き彫りにされ る。多くの環境資源を集積することは一般には困難 なことであり，手に入る限りの流域環境マップの事

*大井川流域ネットワーク

Toshihiko ODA, Kazunari KUROSE
例を見ると欠落した観点を持つものが目立つ. 環境 マップにはすべての観点を網羅しなければならない と考える必要はないが, 流域住民が川との関係を取 り戻す絶好の機会を提供できるものである。そこで 筆者らが関与した瀬戸川の流域環境マップの作成事 例を踏まえて, 流域環境資源調査手法に関する研究 の成果を報告する.

\section{2. 流域調查の目的と考え方}

\section{1 流域調査の目的}

流域に暮らす市民が流域に存在する環境資源に関 する情報を共有していなければ，市民が生かされた まちづくり，地域おこしはできない．環境マップを 整え流域の住民に公開することは，減少衰退の一途 をたどる地域固有の文化や地域の人たちが忘れかけ ていた貴重な自然環境を思い起こし，地域環境の保 全活動，地域を挙げた環境教育活動の推進などに役 立つと考えられる．また，市レべルの基本計画，都 市のマスタープラン，環境基本計画などの重要な施 策立案や環境影響評価を行う場合の基礎資料となり 得るものである.

環境マップの作成は，河川管理者だけでなく地域 の多くの人々が地域の環境資源を認識することで, 地域住民の望む方向に環境保全，復元活動がより活 性化することを目的としている，さらに，川を中心 に展開する地域の自然と文化を掘り起こす過程その ものがまちおこし等の人材教育の原動力となること を実感した．今回の報告では環境（自然，社会）に ついて流域ごとに調査整理する手法と考え方につい て, 具体的な調査事例に基づき報告するものである.

\section{2 流域調査の考え方}

古くから文明は川を中心とした環境に繁栄をして いた．なぜなら人間は水を飲み水としてだけではな く農耕や物流，エネルギー獲得などに活用していた 
からである．また，川は地域の地理的地質的条件に 基礎を置き，生命の多く息づく場所でもあり，美し いふるさとの景観をも形成しているものである。ま たそこを中心に歴史文化を育んできた場所でもあっ た。降雨による流水を集水する範囲として規定され る流域は, 水により地域が繋がっているだけでなく， 自然と文化あるいは産業のユニットとして, 最も基 本的なものと考元られる。つまり，地域特性や風土 を示す自然と人間活動のひとまとまりの単位として 流域をとらえている.日本では特に流域ごとの生活 圈単位に概ね市町村界が区切られている。このよう なことから流域を一つの調査単位と考え，取りまと めを行っている.

一般的に河川は土木行政の管理であるが，同じ水 系の一部分であるのに，同一の河川であっても所轄 する区間が国，県，市町村によって異なっている. さらに，田んぼや農業用水路となると農林行政の管 理になる．同じ水系の一部分であるのに異なる管理 者，管理区域のため，それぞれの事業計画に基づい て河川管理が進行し川の本来の姿を形成できずにい る. そのため，流域全体のあるべき姿が問題とされ ず，各管理担当の範囲だけを考え川と関わること が多かったようだ，今後は，水に関わる各関係機関 や自治体同士の連携・協力が求められ，流域という 観点から総合的に管理することが必要となろう。そ の際, 重要となるのは河川の特質を明確に整理した 上で保全・復元の目標を立てることである.

\section{3 流域環境資源の捉え方}

かつて，人々は暮らしの中で身近に存在する資源 を知恵を使い上手に活用してきた。現在は近代科学 の利便性に浸った日常生活の中にいる結果, 意識せ ずに見過ごされている地域の資源が山ほどある。し かし, 今日科学技術や社会経済の発達の中で忘れて いった価値が見直され始めている。「体験」「地域固 有性」「失われつつある身近な自然」など真の豊か さを求める社会の中で重視されつつある価値観であ る. それは，普段目にしているものかも知れないが, 意識の外にあってその貴重性に気づいていないこと もある．それを顕在化することで初めて資源として 輝きを示すに違いない.すなわち, 資源とはその価 值を評価し明らかにすることで初めて価值を発揮す るものが多い，河川の環境マップに取り上げる環境 資源はその地域の個性を形成する上で欠かせない パーツであり，地域住民の共有財産と言えるもので
ある.

ところが全国各地で進行した都市化の波は地域特 性を眼中におかずに，河川環境から地域性を奪い， 全国共通の排水路へと変えてきた．河川管理者はも ちろん, そこに住む地域の人々も違和感なく，河川 の近代化を当然のように受けとめてきてしまった。

今日，国や自治体は地域らしさに価値を求める時 代へ変化してきたことに充分気づいている，そこで， 地域を特徵づける資源の掘り起こしを早急に行う必 要があるのである.

\section{3．瀬戸川の調査事例}

瀬戸川の環境資源調査の事例を表 1 に示し, さら に，今回特に注目して調査した地域の環境資源を 4 つ選び詳しく述べる。

\section{1 お地蔵さん（写真 1 )}

瀬戸川沿いには数多くの川除地蔵が堤防の随所に 見られる．洪水による川の氾濫に人々が苦しんでい たことを伝える貴重な資源である．地蔵の前は清ら かに掃き清められ香花の絶えることはなかった。こ れまでどれだけ多くの人々が打地蔵さんに手を合わ せていたことだろう。流域の人の心が常に川に向け られていた証であるだけでなく，人々が深く川を愛 し畏れ敬っていたことを示している。また，現代人 にとってもウォーキング等で扔地蔵さんの前を行き 交う時，心が和むふるさとの雲囲気を伝える好まし い存在になっていると思われる。

\section{2 巨木}

川ベりにそびえる巨木は, 川の作り出す景観に貴 重なアクセントを添えている．単にランドマークと して重要なだけではなく，川に多くの人や生物を誘 致する機能が優れている，木陰が子どもにとって多 様な遊び場を与えてくれる．例えば木登りしたり， かくれんぼしたりと，鑑賞用の桜並木とは異なる魅 力がある. 夏の強い日差しから身を守る日㓌は，川 辺に人々が集うのに適した空間を演出してくれる.

また，水辺の大きな木は河川にいろいろな生命を 呼ぶ力があり，野生の生き物にとってビオトープを 提供している．例えば，河畔林の代表的樹種である エノキにはオオムラサキやゴマダラチョウの幼虫が 育ち，古い枝からきれいな七色をしたタマムシが発 生している。秋につけるたくさんの実は野鳥のエサ となる. 大量の枯葉は程よい栄養を土堤や河川に提 供し様々な生物を発生させている. 
表 1 河川の環境資源調查内容（瀬戸川の事例）

\begin{tabular}{|c|c|c|c|}
\hline \multicolumn{2}{|c|}{ 調査項目 } & 環境資源 & 主とした調查方法 \\
\hline \multirow[b]{3}{*}{ 自然 } & 動物 & ·魚類, 鳥類など & 地域の活動団体の専門家に聞き取り調査, 既存資料調查 \\
\hline & 植物 & $\begin{array}{l}\text { ·貴重な植物 } \\
\text { 巨大, 特徵ある樹木 ○ } \\
\cdot \text { 河畔林, 屋敷林, 防風林,樹林带 @ } \\
\cdot \text { 河川内の植生 }\end{array}$ & $\begin{array}{l}\text { 地域の活動団体の専門家に聞き取り調査, 既存資料調查 } \\
\text { 専門家調查, 一般樹種についてい市民参加 } \\
\text { 航空写真とフィールド調查 } \\
\text { 航空蒖とフィールド調查, 専門家調查 }\end{array}$ \\
\hline & 水辺 & 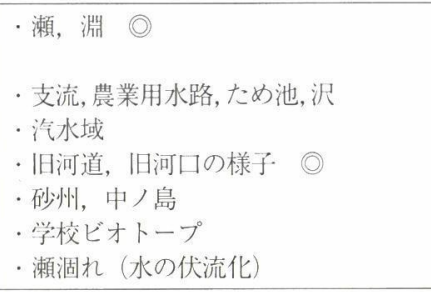 & 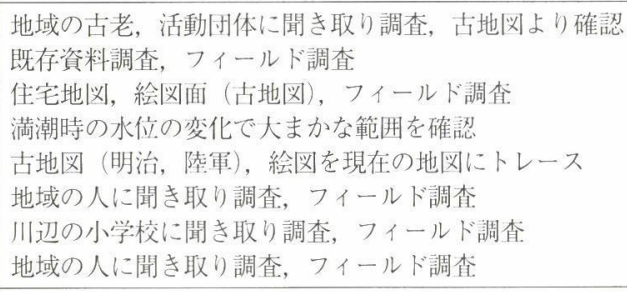 \\
\hline \multicolumn{2}{|c|}{ 歴史, 民俗 } & 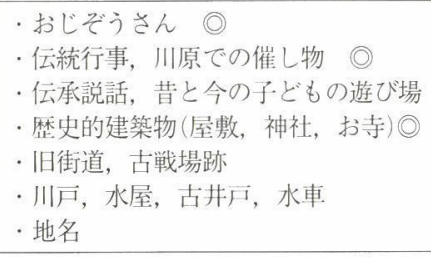 & $\begin{array}{l}\text { 地域の古老や活動団体, 専門家に聞き取り調査, } \\
\text { 市誌などの既存資料調查, フィールド調査 }\end{array}$ \\
\hline \multicolumn{2}{|c|}{ 生活, 文化 } & 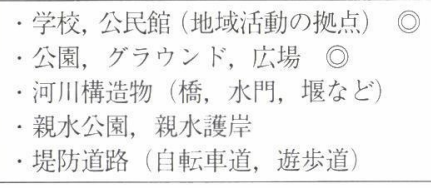 & 住宅地図, 都市計画㘠, フィールド調査 \\
\hline \multicolumn{2}{|c|}{ その他 } & $\begin{array}{l}\text { •ランドマーク } \\
\text { ·景観 }\end{array}$ & $\begin{array}{l}\text { 観光案内, 市民からのアンケート, } \\
\text { 地域の古老からの聞き取り }\end{array}$ \\
\hline
\end{tabular}

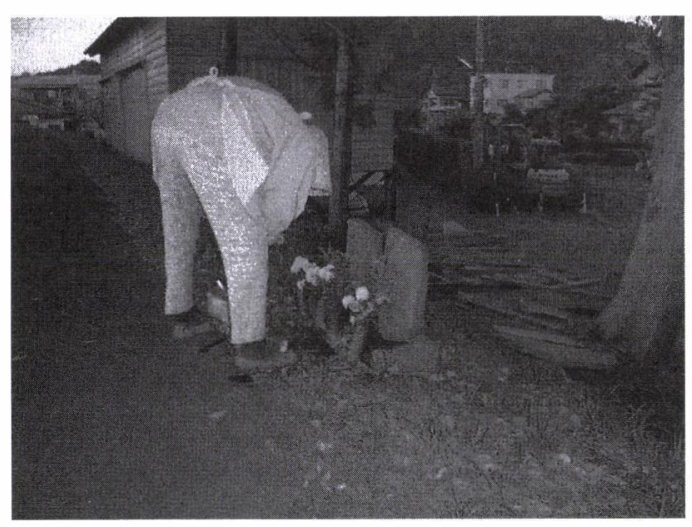

写真 1 お地蔵さんに花を供えるお年寄り

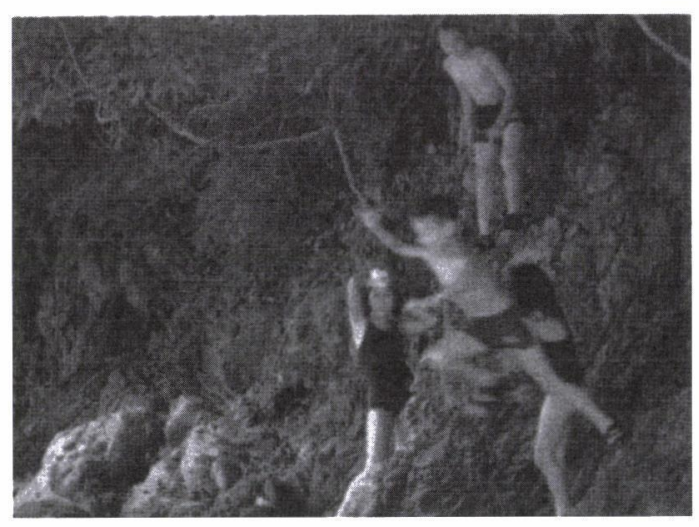

写真 2 山鼻淵で遊ぶ子供たち

\section{3 淵 (写真 2)}

河川の構造を端的にあらわすと瀬・淵という河床 の変化で表される．生物学的に水生昆虫の多い瀬は 多くの魚類にとって餌場として機能することが多 い. 産卵を行う繁殖環境は種類によって様々である。

川にくらす生き物にとって瀬と淵の存在は生活をす る上での重要なハビタットである.

これまでの河川整備における河道のショートカッ ト, 川岸のコンクリート化等は水の流れを変化させ, 数多くの多様な淵を消失させてきた，本来，川の形 
状上水衝部となる箇所は水力により洗掘され淵が形 成されてきたが，現在は，水衝部の位置が河川整備 により消失したり移動し, 従来の淵には土砂が堆積 して異なる構造に変化している.

瀬戸川においても川のメリハリのきいた瀬・淵の 構造が変貌し, 全国共通な単一化した川の流れと水 辺の構造となっている。その結果, 多くの名だたる 淵が消失してしまった，例えば，馬がカッパによっ て淵の中に引きずり込まれたというカッパ伝説があ る「鴊洗淵」や，弘法大師が水涸れの時にそこで水 を湧かしたといわれ，地域の人がお地蔵さんをまつ っている「弘法淵」などいわれのある淵がある。ま た，淵の所に大きな岩が立っている「立岩淵」や岩 の形が獅子の鼻に似ていることから名づけた「獅尔 算淵」など，そこの淵の特色ある景観を表している ものもある. しかし現在, 馬洗淵や弘法淵は消失し, 道路に変わったり, 護岸整備により土砂に埋没した りしている。

瀬・淵の現状やかつての瀬・淵の分布状況を記録 し比較することは重要なことである，それは，河川 の自然環境の多様性をよく指標するものであるから である。また，淵の呼び名を聞き取り取材すること で精度や再現のある情報が得られる。

川辺にたたずむ古老に淵のことをたずねると誰も が口をそろえて子どもの頃の原体験の話をする。 「夏，川で露頭した大きな岩壁の上からたっぷりと 水をたたえた深い淵の中に飛び込むことが楽しくて しょうがなかった」と。

\section{4 川にまつわる年中行事}

瀬戸川ではお盆の頃の伝統行事として「あげんだ

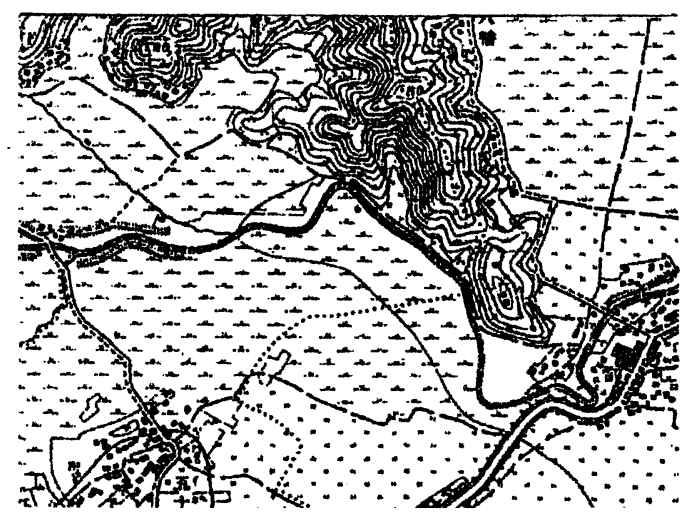

い」「精恿流し」，「龍勢」などの水辺で火を用いた 行事が行われている。これは, 東海型河川を特徽づ ける砂礫で形成された広い川原を有する河川ならで はの年中行事であり，広い川原を生かした 1 つの川 原文化と言えるものである。また，竹や橲を用いる 点でも地域の特質を強く反映させている. はるか海 のかなたの黄泉の国からご先祖様の霊が川を上って 村々に帰って来るという信仰であり，海と山を結び つける川の働きを認識させるものであり，川を中軸 に据えた世界観が表現されている。

\section{4. 環境資源の掘り起こし方法}

\section{一市民参加型のワークショップ方式一}

瀬戸川の河川整備計画原案の策定で河川管理者 は, これからの目指すべき河川のあり方の提案を得 るため, 流域住民の意見の集約, 地域の環境資源を 掘り起こす手法としてワークショップを開催した. 河川や自然環境に対する様々な考え方を持ちこれか らの地域づくりに積極的に関わりを持つ意識の高い 一般の市民を対象に開催された.

ワークショップとは多くの参加者が意見交換や共 同作業を行いながら進める体験的参加型で作業や学 習を進める形式のことである. 意見の拾い出しや集 約の手法としてはブレインストーミング, kj 法など がある．参加者が受け身でなく積極的に発言し他者 の意見から「学び，気づき」を受け，合意形成を図 り意見の集約をしていく方法である.

参加者が流域内のことをすべて把握している訳で はもちろんない. 参加者に具体的な共通のイメージ を持ってもらうことが重要なため, 現地観察会を

明治22 年

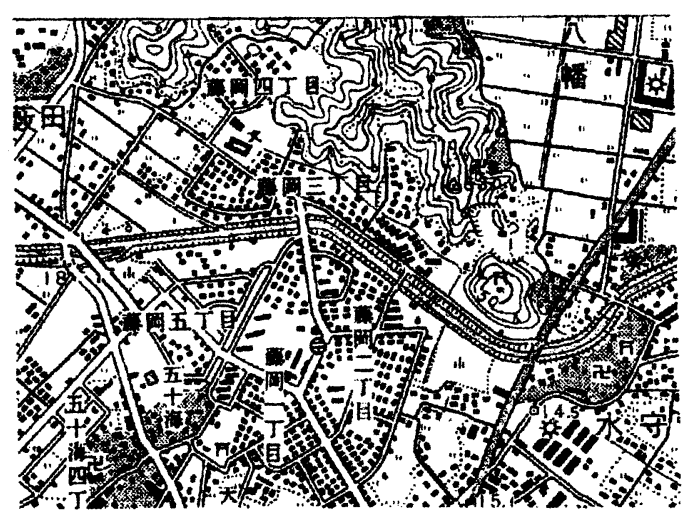

平成 7 年

図-2＼cjkstart作成年度の異なる地形図の比較

流路 (河道) の変更や周囲の土地利用の変化が読み取れる. 
ワークショップの初めに行った．参加者は自分の目 で河川を改めて眺め，河川管理者の話や所々で地域 の古老の話を直接聞くことで教えられた情報だけで なく，自分の「観察」で得た情報を整理していた。 資料として目印となる施設の名称等が記入された地 図を与えられ，6〜10人程度の班ごとに現地を観察 しながらディスカッションを行った.

参加者は地図にそれぞれの思いの場所を記入して いて，ある参加者の地図には地域の歴史研究家から 聞いた現在では地域に埋もれている史跡や扮地蔵さ んのいわれなどを記入していた。

とりまとめの作業は河川が望める近くの公民館で 行われた．参加者はグループごとに現地調査の結果 を話し合いながら,地図にとっておきの場所や改善が 望まれる場所, 復元を希望する箇所を記入していっ たそその際には地域の古老から聞いた昔の子どもた ちがよく遊んだ淵の位置やこの地域の河川特有現象 などの情報も書き込まれていた。

この地図が私たちの考える流域環境マップそのも のであった。ワークショップにおいて現地観察, 環 境マップの作成は参加者の流域環境に対する意識の 共有化が図れ，知識だけでなく川への関心を向上さ せ，新たな環境資源の掘り起こしに非常に役立つ手 法と考える.

\section{5 . 今後の展開}

今回作成した流域環境マップは 2 次元的な整備に 限られた紙面の制約から, 位置の情報と写真, 名称 等の情報が多量であるため，位置情報と資料（文献） の管理が別々となり分割保存となってしまう欠点が ある。

デジタル化が進む現在では，コンピュータを有効 に活用し各環境分野ごとの情報層（レイヤ）や調査 年代ごとの層を用意し，たとえば樹木の位置と神社 等の位置情報を別々な層に書き込みし，属性情報と 関連づけを行い必要なときに重ねて表示でき, 検索, 解析に利用できる地理情報システム（GIS）の活用 が考えられる。

GISは地理的な位置と属性データベースとを関連 づけさせて視覚的に表示できるようにした仕組みで あり，簡単な事例としては商圈分析（エリアマーケ ティング）が挙げられる。決められたエリアの人口 分布データ, 出展位置との関係を計算し理想的な出 展位置を解析するシステムである。
位置，属性情報，時間軸のデータベースを作成し て適切な管理を行って必要なときに組み合わせをし て表現を行うシステムの作成にはデータの作成や解 析の仕組みづくりに多額の費用が必要なことからす ぐに可能な取り組みではないが，将来的には必要性 の高いものと考えている.

そのために今行われている調査, 研究などのデー 夕作成にあたっては，統一されたルールに基づきデ ジタルデータ化されることが絶対に必要である. 既 に調査済みの成果については徐々にデジタルデータ 化を行わなければならないが，現在から将来にわた る成果についてルールを決めて保存されていけばコ ストの削減につながる。

統一されたルールづくり，作成された成果の一元 的な管理，地図デー夕の整備など各地域ごとに管理 を行う組織作り（本の管理における図書館のような 仕組み) が早急に望まれるところである。

\section{6.あとがき}

子どもたちが群れを成して家の外で遊ぶ姿を見か けなくなってから多くの時間が経過している.一方， スポーツ少年団などの活動に参加している子どもた ちは，くたくたになるまで運動漬けの毎日である。

昔の子どもたちは，身近な地域資源（里山，田園， 小川, 神社, 河川, 遊水池等) とそこに棲む生き物 (人間も含む)と一体となって遊んでいた，そのこ とが，真・善・美・聖などの価値観や人間性を養う ために重要な機能を果たしていたのではと考える. 子どもの頃にふるさとの山河で充分な原体験をもつ 人々は，かつて遊んだ川や里山の姿が変わりそこに 生息していた魚や生き物の姿も見えないことに驚 く．子どもたちの生活が川から遠くなっていること に気がつき，疑問を持つ人々が増えてきている，環 境教育の目的の一つとして，「人と環境との関わり について理解を深め, 責任ある行動をとれるように すること」が掲げられている．地域の宝物調査を企 画し，川を調べてみようと行動することこそが環境 教育の一歩となり得るのではと考える.

子どもたちにふるさとの自然環境で原体験をさせ たいという思いが流域の多くの人々にあり，子ども たちに遊びや調査を通じて環境（自然，歴史，文化) を洞察する力を養ってほしいと願っている. そこで, 完成した流域環境マップを小学校等の総合学習でそ のまま子どもに示すだけでなく,指導者のバックデー 
タとして利用し, 子どもたちの学習達成度に応じた マップの活用が望まれる。

また，近年，家庭でも老人との会話が少なくなっ て, 昔からの言い伝え, 風習などの伝承が途切れて しまう危惧がある．早急に伝承説話の調査等が進め られることが望まれ，調査結果を流域環境資源マッ プに蓄積が図られるよう願うものである.

そのために，行政の適切なバックアップにより市
民参加による協働作業を支援する地域ボランティ ア, NPOの今後の活躍が期待される.

今回の報告文を参考にたくさんの地域で地域特有 な環境マップの作成が進められることを望み，今回 の調査にあたりご協力をいただいた瀬戸川流域自然 と文化フォーラムの皆様, 富士常葉大学山田先生に 感謝の気持ちを伝え報告書の結びとするものであり ます。

\section{会 告}

2001年 3 月

\section{書店を通して年間講読を いただいている皆様へ}

\section{「年間講読料」改定とご入会のお願い}

これは，小会より直接雑誌をお送りしている「会員」のみなさまではなく，書店を通して本誌を年間講 読いただいている「年間講読者」のみなさまへのお願いです.

みなさまには日頃より「環境技術」をご講読いただきましてありがどうございます。心よりお礼申し上 げます．ご承知いただいておりますように，本誌は学術団体の機関誌です．したがいまして現在各書店を 通じて本誌を定期講読していただいている読者のみなさまは，小会に直接ご入会いただいている「会員」 とは異なり，「年間講読者」という位置づけになります。

本来，小会は，学術団体として会費収入と会員の交流，諸活動に支えられて，協会運営がなされており ます．そのため「年間講読者」の方には，できるだけ「会員」になっていただく，つまり小会へのご入会 を日頃よりお願いいたしております。

しかし残念ながら，やむを得ぬ事情によりご入会がご無理な場合もございます。つきましては，勝手な がら, 新しい講読料請求の時より，年間講読料を，現行の会員会費と同額の18,000円から20,160円に，改 めさせていただきたくお願い申し上げます。

この金額は，「環境技術」を定価でお求めいただいた場合と同額の金額となっております。このたびの 措置は小会の活動のさらなる発展を目指して, 会員層の把握と, 共有するテーマの構築を可能にするため の一段階とご理解いただければ幸いに存じます．どうかよろしくお願い申し上げます。

なお，この機会にぜひご入会手続きも併せてご検討いただきますようお願い申し上げます.

環境技術研究協会 tel 06-6357-7611 fax 06-6357-7612 